\title{
The relationship between leaf area and basal area growth in jack and red pine trees
}

\author{
by Margaret Penner and Godelieve Deblonde
}

\begin{abstract}
Relationships between leaf area and sapwood area, sapwood area and basal area, and leaf area and basal area growth are determined for jack pine and red pine. The relationships vary with species and stand origin. Growth efficiency (basal area growth per unit leaf area) is relatively independent of tree size under all but the densest conditions. Observed changes in the leaf area to leaf mass ratio from July to October indicate that allometric relationships vary seasonally. A procedure is outlined for obtaining estimates of stand leaf area index (LAI). These estimates may be used to calibrate instruments that measure LAI and, subsequently, to predict forest productivity.
\end{abstract}

Key words: leaf area index, basal area, growth efficiency, red pine, jack pine, sapwood area

\section{Introduction}

Leaf area index (LAI), the one-sided projected area of foliage above a given unit area of ground, is an important measure of the potential productivity of a vegetated area because it indicates the extent of site occupation with respect to light interception. This measure has been used as a driving variable in forest growth models (Running et al. 1989; Korol et al. 1991) because of its close relationship to radiation interception by leaves, which, in turn, is a major determinant of tree growth (Vose and Swank 1990). Direct measurement of LAI is time consuming and involves destructive sampling. Therefore, much attention has been directed toward estimating LAI using allometric relationships and the extent of light interception by canopies. However, the latter method has given inconsistent results due to the need to calibrate instruments against allometric-derived LAI estimates (Smith et al. 1991; Deblonde and Penner 1994). There is a need, therefore, for more efficient destructive sampling methods to estimate $\mathrm{LAI}$ and to provide data for calibrating instruments that measure LAI using light interception or remote sensing measures. The present study uses destructive sampling to estimate predictive relationships between leaf area and basal area growth for several red pine (Pinus resinosa Ait.) and jack pine (Pinus banksiana Lamb.) stands.

The pipe model theory of Shinozaki et al. $(1964 \mathrm{a}, \mathrm{b})$ predicts that the foliage weight above a given point in the crown is linearly related to the sum of branch and stem cross-sectional areas. This relationship between leaf mass and conducting area has been quantified for a variety of coniferous and deciduous tree species (Kaufmann and Troendle 1981; Waring et al. 1982;

\footnotetext{
${ }^{1}$ Petawawa National Forestry Institute, Canadian Forest Service, Chalk River, Ontario, Canada K0J $1 \mathrm{JO}$.

${ }^{2}$ Atmospheric Environment Service, 2121 Transcanadian Highway, Dorval, Quebec, Canada H9P $1 \mathrm{~J} 3$.
}

Les relations entre la surface des feuilles et la superficie de l'aubier, la superficie de l'aubier et la surface terrière, et la surface des feuilles et la croissance de la surface terrière sont établies pour le pin gris, le pin blanc et l'épinette rouge. Les relations varient en fonction de l'espèce et de l'origine du peuplement. L'efficacité de la croissance (l'augmentation de la surface terrière par unité de surface foliaire) est relativement indépendante de la taille de l'arbre pour toutes les conditions de densité à l'exception des plus denses. Les modifications observées entre la surface et la masse foliaire entre les mois de juillet et octobre indiquent que les relations allométriques varient en fonction des saisons. Une procédure est identifiée pour obtenir des estimés de l'indice de la surface foliaire d'un peuplement (ISF). Ces estimés peuvent être utilisés pour calibrer les instruments servant à mesurer l'ISF et, en conséquence, pour prédire la productivité forestière.

Mots clés: indice de la surface foliaire, surface terrière, efficacité de la croissance, pin rouge, pin gris, superficie de l'aubier
Marshall and Waring 1986; Robichaud and Methven 1992). Some studies indicate, however, that this relationship may not be constant for a given species. Stand and site conditions may affect sapwood permeability (Pothier et al. 1989, Yang and Hazenberg 1992) which, in turn, may affect the sapwood area to leaf area relationship. Species-specific relationships for balsam fir [Abies balsamea (L.) Mill] and red spruce (Picea rubens Sarg.) were independent of stand condition or individual tree vigour (Marchand 1984). Results from other investigators suggest that the leaf area to sapwood area ratio varies with stand density, site (Long and Smith 1988), using lodgepole pine (Pinus contorta var. latifolia Dougl.), and sapwood ring width (Espinosa Bancalari et al. 1987). Basal area growth is also a predictor of foliage mass (Snowdon 1987) and can be predicted from light interception (Law et al. 1992). Oren et al. (1987) related LAI to stem volume production, but the low sapwood area at $1.3 \mathrm{~m}(<3 \%$ of the basal area was sapwood) limits the applicability of results.

This paper outlines a method for estimating LAI using allometric relationships to link leaf area to growth. The method is demonstrated for two pine species.

\section{Field Methods}

The sites are part of the Petawawa Research Forest which falls within the Great Lakes - St. Lawrence forest region. The region is characterized by white pine (Pinus strobus L.), red pine, and shade-tolerant hardwoods, as well as a mixture of boreal conifers at the southern edge of their range. The mean January and July temperatures are $-12.9^{\circ} \mathrm{C}$ and $19.0^{\circ} \mathrm{C}$, respectively; the average precipitation is $833 \mathrm{~mm} \mathrm{yr}^{-1}$, and there are 1773 growing degree days above $5^{\circ} \mathrm{C}$ (30-year normals for 1951-1980).

Seven stands were sampled in July 1992 (Table 1). Full needle elongation was not yet complete but sampling was timed 
Table 1. The estimated values of basal area and leaf area index for the stands examined

\begin{tabular}{lcc}
\hline Stand name & Basal area $\left(\mathbf{m}^{\mathbf{2}} \mathbf{h a}^{\mathbf{1}}\right)$ & Leaf area index \\
\hline pj01 & 17.3 & 1.56 \\
pj02 & 28 & 2.24 \\
pj03 & 20.7 & 1.65 \\
pj04 & 20.5 & 1.48 \\
pr01 & 29.3 & 2.91 \\
pr02 & 43.3 & 4.88 \\
pr05 & 57.3 & 6.24 \\
\hline
\end{tabular}

to coincide with another investigation. The three jack pine plantations and one fire-origin jack pine stand were approximately 28 years old. The three red pine plantations were approximately 60 years old and two had been periodically thinned to various basal areas. Three temporary sample plots (TSPs) were established in each plantation, and four TSPs in the fireorigin stand. The TSPs were a minimum of $50 \mathrm{~m}$ from stand boundaries.

In the TSPs, all trees selected by a prism (basal area factor of $\left.2 \mathrm{~m}^{2} \mathrm{ha}^{-1}\right)$ were tallied by species and diameter at breast height $(\mathrm{dbh})$ (stem diameter including bark at $1.3 \mathrm{~m}$ ). The first five trees encountered were also sampled for height and length of live crown, and cored at breast height $(1.3 \mathrm{~m})$ to determine age, sapwood width, and sapwood age. Trees outside the TSPs, but within the same stand and representative of the range of dbhs, were selected for destructive sampling (Table 2).

The following measurements were taken at breast height on the destructively sampled trees: sapwood width, number of sapwood rings, number of heartwood rings, and diameter. Total tree height was recorded as well as diameter at the base of the live crown. The base of the live crown was located by finding the lowest whorl with live foliage on two or more branches and the stem within the live crown was divided into three equal lengths. The stem was cut into sections approximately $1 \mathrm{~m}$ long below the base of the live crown; within the live crown, the sections were cut to include approximately two whorls each. Branches were removed from the stem by section and the fresh weights of the stem and all of the branches (including foliage) were recorded to the nearest gram. Within each third of the live crown, two sections ${ }^{1}$ were randomly chosen and a branch randomly selected from each section for a total of six branch samples per tree. These crown branch samples were returned to the laboratory to determine the branch, old needle ( $>1$ year old), and current needle ( $<1$ year old) fresh weight fractions and moisture contents. In October, additional branch samples were shot from the crown and processed to determine whether or not the specific leaf area (leaf area/dry weight) varied through the growing season.

\section{Laboratory Methods}

In the laboratory, the branch samples were separated into woody biomass, current year foliage, and older foliage components. Samples of 25 needles of current foliage and 25 needles of older foliage were taken from each crown sample and the fresh weight and leaf area recorded. The leaf area, unless

\footnotetext{
${ }^{1}$ On smaller trees ( $<2 \mathrm{~m}$ high) only one branch was sampled from each third of the live crown.
}

Table 2. The destructively sampled trees ${ }^{1}$

\begin{tabular}{|c|c|c|c|c|}
\hline Species & $\begin{array}{c}\text { Number of } \\
\text { sampled trees }\end{array}$ & dbh (cm) & Height (m) & Age (years) \\
\hline Jack pine & 13 & $\begin{array}{c}15.1 \\
(3.1-27.5)\end{array}$ & $\begin{array}{c}14.9 \\
(5.0-20.8)\end{array}$ & $\begin{array}{c}28 \text { at } 1.3 \mathrm{~m} \\
(16-43)\end{array}$ \\
\hline Red pine & 20 & $\begin{array}{c}20.0 \\
(10.1-37.9)\end{array}$ & $\begin{array}{c}18.4 \\
(10.6-26.9)\end{array}$ & $\begin{array}{c}36 \text { at } 1.3 \mathrm{~m} \\
(21-57)\end{array}$ \\
\hline
\end{tabular}

${ }^{1}$ Means are followed by ranges in parentheses.

stated otherwise, refers to the one-sided projected leaf area and was measured using an Agvision system (Decagon Devices 1989). Fresh weights of the branch components were recorded and the samples dried at $70^{\circ} \mathrm{C}$ for a minimum of $48 \mathrm{~h}$. The moisture content was computed as the difference between the fresh and dry weights divided by the fresh weight. The additional branch and foliage samples obtained in October were examined to assess seasonal variations.

The crown samples were aggregated by crown third and the fraction of the crown sample fresh weight in each component (branchwood, current foliage, and older foliage) was computed and multiplied by the component moisture content. These fractions were then used to convert the crown section fresh weights to dry weights by component,

foliage $_{\mathrm{d}}=(1-$ foliage moisture content $) \times$ branch $_{\mathrm{f}} \times$ foliage fraction $_{\mathrm{f}}$

where the subscript $d$ refers to dry weight and the subscript $f$ refers to fresh weight.

The two 25-needle samples were combined within each crown third and the specific leaf area (SLA) was computed as

$$
\text { SLA }=\frac{\text { leaf dry area }}{\text { leaf dry weight }}
$$

with separate estimates for both current needles and older needles. Tree leaf area was obtained by summing the product of leaf dry weight and SLA for the crown sections.

The relationship

leaf area $=\beta_{1} \times$ sapwood area

was tested as a suitable model for predicting leaf area per tree based on the destructively sampled trees, where $\beta_{1}$ is estimated by minimizing the squared error. Biologically, an equation that predicts no leaf area when there is no sapwood area is more reasonable, so the contribution of an intercept was tested for significance. Sapwood area was determined at breast height or at the base of the live crown if the live crown extended lower than $1.3 \mathrm{~m}$. The logarithmic transformation of the data suggested by Waring et al. (1977) did not improve predictions.

The following linear model was fit by species and stand using cores taken from trees in the TSPs, with $\beta_{2}$ being the least squares coefficient:

sapwood area $=\beta_{2} \times$ basal area

The stand LAI was then computed from the TSP measurements and Equations 3 and 4 . The periodic basal area growth was determined by dividing the sapwood area at breast height by the num- 
ber of sapwood rings. This gives an average of the annual basal area growth of the past several years. Principal component analysis was used to relate basal area growth and leaf area. Unlike linear regression equations, principal component relationships are invariant with respect to which variable is designated dependent and which is independent. As well, using leaf area as a predictor in a linear regression would violate the assumption that the independent variable is fixed and free of measurement error. All statistical tests were conducted with a significance level of $\alpha=0.05$.

\section{Results and Discussion \\ Prediction of Leaf Area}

The specific leaf area of the current foliage (SLA) decreased significantly over the growing season whereas that of the older foliage $\left(\mathrm{SLA}_{\mathrm{o}}\right.$ ) remained relatively constant (Table 3 ). For the October sampling date, SLA $_{c}$ was not significantly different from SLA. The decrease in SLA with increasing needle age also corresponds to a decreasing photosynthetic rate per unit leaf area (Oren et al. 1986).

The predictive models are illustrated (Figs. 1 and 2) the fit was good. The sapwood that acts as a conduit of water between the roots and the rest of the tree has been shown to taper below the base of the live crown (Waring et al. 1982). Using the sapwood area at the base of the live crown avoids inclusion of the effect of this taper, but increases the difficulty of obtaining nondestructive measurements on tall trees. In this study, the sapwood area at $1.3 \mathrm{~m}$ was used to facilitate obtaining accurate and nondestructive measurements by tree coring.

The relationship between sapwood area and leaf area showed minimal variability with stand density, unlike the results obtained by Long and Smith (1988) who looked at a wide range of densities of lodgepole pine.

The coefficient relating basal area to sapwood area was influenced by stand conditions and was significantly different for each stand. However, the coefficient did not have a high correlation with any of the stand attributes examined, including density, live crown ratio, and quadratic mean $\mathrm{dbh}$. Therefore, to obtain stand-specific LAI estimates, a separate relationship between basal area and sapwood area should be calculated for each stand.

Although the differences between stands were statistically significant, the additional work involved in estimating separate equations for each stand, rather than using a speciesspecific equation for all stands of the same species, may not be justified. The maximum error in estimating LAI using a species-specific relationship, which is more general, rather than a stand-specific relationship, was $6.5 \%$ for jack pine and $9 \%$ for red pine.

\section{Prediction of Basal Area Growth}

The relationship between leaf area and basal area growth is plotted (Fig. 3) and modelled (Table 4). The relationships between leaf area and periodic basal area growth are good. As none of the intercepts were statistically different from zero and an intercept is not biologically reasonable, only the slope coefficient was retained. The jack pine plantations had a common relationship, as did the red pine plantations. The fireorigin jack pine (pj04) was significantly different and also showed some signs of reaching an upper limit.

The differences in leaf area to basal area growth relation-
Table 3. Specific leaf areas obtained in July from destructively sampled trees and in October from branch samples shot from the canopy

\begin{tabular}{|c|c|c|c|}
\hline Species & Sampling time & $\begin{array}{l}\text { Specific leaf area } \\
\text { of new needles } \\
\left(\mathrm{cm}^{2} \mathrm{~g}^{-1} \pm \mathrm{sd}\right)\end{array}$ & $\begin{array}{l}\text { Specific leaf area } \\
\text { of old needles } \\
\left(\mathrm{cm}^{2} \mathrm{~g}^{-1} \pm \mathrm{sd}\right)\end{array}$ \\
\hline Jack pine & July 1992 & $65.5 \pm 8.2$ & $42.2 \pm 5.7$ \\
\hline Red pine & July 1992 & $53.9 \pm 2.5$ & $36.0 \pm 2.4$ \\
\hline Jack pine & October 1992 & $43.4 \pm 2.2$ & $39.9 \pm 1.6$ \\
\hline Red pine & October 1992 & $36.1 \pm 3.5$ & $33.7 \pm 1.9$ \\
\hline
\end{tabular}

${ }^{1}$ One year and older.

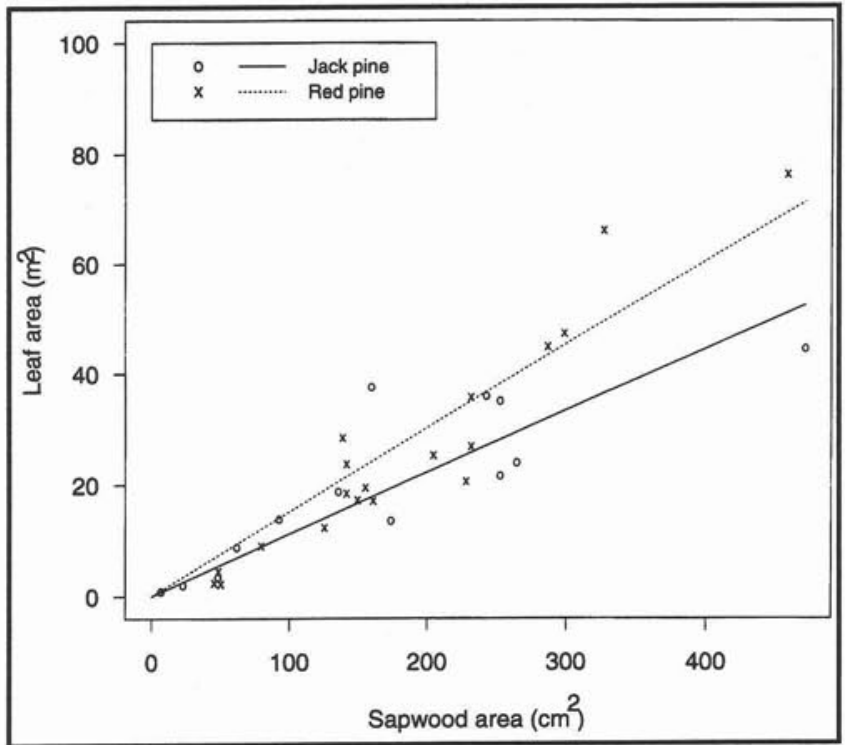

Fig. 1. Relationship between sapwood area at $1.3 \mathrm{~m}$ and leaf area for destructively sampled trees. The equations are as follows: jack pine, leaf area $\left(\mathrm{m}^{2}\right)=0.1113 \times$ sapwood area $\left(\mathrm{cm}^{2}\right)$, for red pine, leaf area $=0.1513 \times$ sapwood area, and for white pine, leaf area $=$ $0.7252 \times$ sapwood area.

ships between species were pronounced, with red pine achieving less than half the basal area growth of plantation jack pine. This may be due, in part, to the greater size (and age) of the red pine trees relative to the jack pine trees. The red pine trees examined in this study have a greater amount of nonfoliated stem than the jack pines, leading to increased translocation costs and higher sapwood volumes, which, in turn, lead to increased maintenance respiration costs. This is supported by the similar LAI to basal area growth relationships of the mature jack pine and the mature red pine. The red pine plantations are not as efficient at converting intercepted light into stem growth. This decrease in tree growth per unit leaf area with increasing LAI agrees with the results of Oren et al. (1987).

Growth efficiency, defined here as basal area growth per unit leaf area, was related to tree basal area. In the pine plantations, growth efficiency did not vary significantly with basal area except for stand pr05, which showed slightly declining growth efficiency with increasing tree size $(\alpha=0.04)$. The range in growth efficiency for jack pine was $0.53-0.80 \mathrm{~cm}^{2}$ of basal area growth $\mathrm{yr}^{-1} \mathrm{~cm}^{-2}$ of leaf area; for red pine, the range was $0.17-0.27 \mathrm{~cm}^{2} \mathrm{~cm}^{-2} \mathrm{yr}^{-1}$. The densest jack pine (pj04) and red pine (pr05) show some signs of decreasing growth efficiency with increasing tree size. Thus, in these stands where competition is great, small trees have marginally better aboveground growth efficiency. 

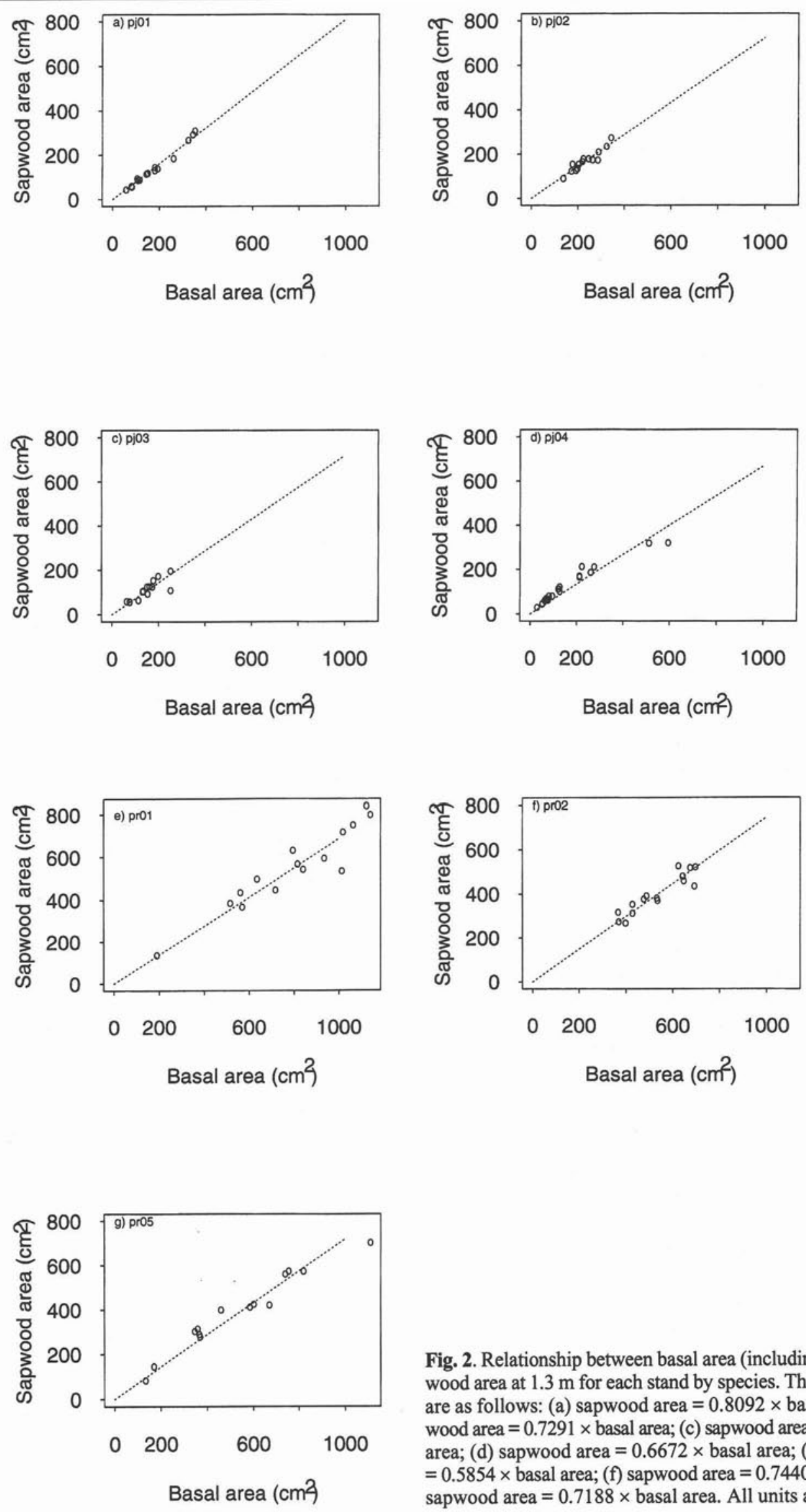

Fig. 2. Relationship between basal area (including bark) and sapwood area at $1.3 \mathrm{~m}$ for each stand by species. The equations areas are as follows: (a) sapwood area $=0.8092 \times$ basal area; (b) sapwood area $=0.7291 \times$ basal area; $(c)$ sapwood area $=0.7171 \times$ basal area; (d) sapwood area $=0.6672 \times$ basal area; (e) sapwood area $=0.5854 \times$ basal area $;(\mathrm{f})$ sapwood area $=0.7440 \times$ basal area $;(\mathrm{g})$ sapwood area $=0.7188 \times$ basal area. All units are in $\mathrm{cm}^{2}$. 

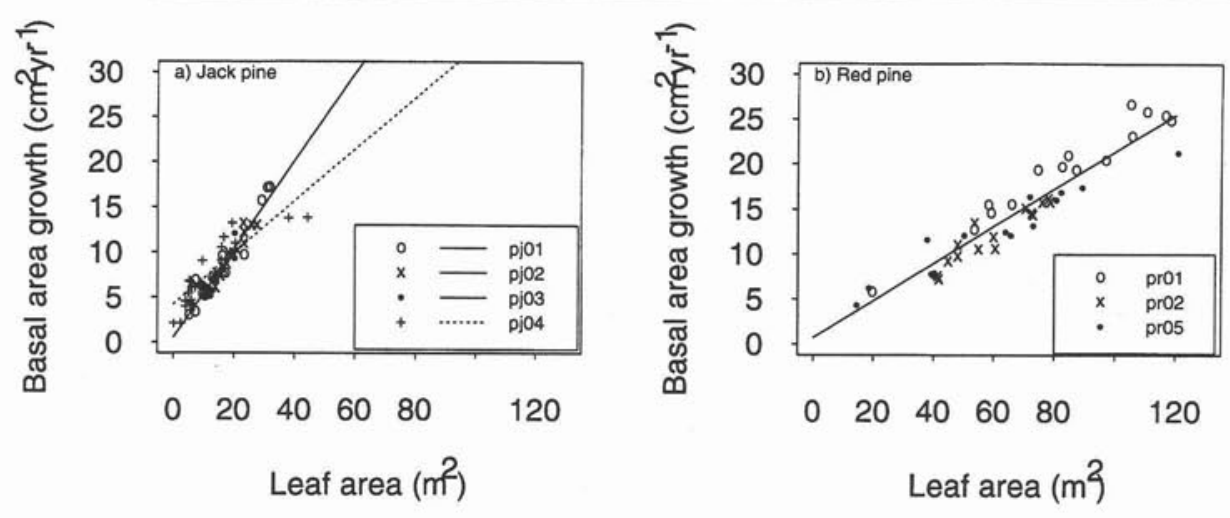

Fig. 3. Principal component relationship between basal area growth and leaf area by predominant species. Stand pj04 is different from the plantation jack pine. The red pines share a common line. Equations are given in Table 4.

\begin{tabular}{|c|c|c|c|}
\hline Species & Stand & Model & $\begin{array}{l}\text { Error mean } \\
\text { square }^{2}\end{array}$ \\
\hline $\begin{array}{l}\text { Jack pine } \\
\text { Jack pine } \\
\text { Red pine }\end{array}$ & $\begin{array}{l}\text { pj01-pj03 } \\
\text { pj04 } \\
\text { All }\end{array}$ & $\begin{array}{l}\mathrm{ba}^{3} \text { growth }=0.489 \times \mathrm{la} \\
\mathrm{ba} \text { growth }=0.286 \times \mathrm{la} \\
\mathrm{ba} \text { growth }=0.206 \times \mathrm{la}\end{array}$ & $\begin{array}{l}0.987 \\
0.981 \\
0.996\end{array}$ \\
\hline
\end{tabular}

${ }^{1}$ Basal area growth $=$ sapwood area/number of sapwood rings.

${ }^{2}$ Proportion of variation explained by the first principal component.

${ }^{3} \mathrm{ba}=$ basal area at breast height $\left(\mathrm{cm}^{2}\right), \mathrm{la}=$ leaf area $\left(\mathrm{m}^{2}\right)$.

\section{Comparison with Other Studies}

Specific leaf area estimates in the current study are similar to those reported by McLeod and Running (1988) for ponderosa pine (Pinus ponderosa Laws.). The decrease in SLA with needle age observed in the current study supports the results of Gholz et al. (1976) for western species, including Pseudotsuga menziesii (Mirb.) Franco var. menziesii, Tsuga heterophylla (Raf.) Sarg., and various Abies species.

The models predicting leaf area from sapwood area for red pine and jack pine compare favourably with those of Waring et al. (1982), who found a slope of 0.15 for Pinus contorta and larger slopes for more shade-tolerant species (up to 0.63 for Abies amabilis). More shade-tolerant species retain foliage at lower light levels and have larger amounts of foliage per unit conducting area. The precision of the predictive models is quite good, although not as good as the results obtained by Woods et al. (1991), who recommended sampling additional trees even with less precise measurement.

Results of the current study (Table 1) are similar in magnitude to those of Bolstad and Gower (1990), who found projected LAIs of $6.2 \pm 0.4$ for red pine plantations with a basal area of $67.6 \pm 4.9 \mathrm{~m}^{2} \mathrm{ha}^{-1}$. These values compare favourably with stand pr05 of the current study. Stand pr01 compares well with the stand studied by Law et al. (1992) which had 309 stems $\mathrm{ha}^{-1}$ and a basal area of $29.6 \mathrm{~m}^{2} \mathrm{ha}^{-1}$. Law et al. (1992) estimated the LAI to be 2.85 , close to the value of 2.91 obtained here.

The relationship between basal area growth and leaf area reported in the current study is an improvement on the relationship between basal area growth and visible light interception reported by Law et al. (1992), which included all crown ele- ments. Law et al. (1992) did not distinguish between light intercepted by foliage and light intercepted by branches and other nonfoliar elements, which increases light interception but may not contribute to growth potential. Although light interception may be more convenient to measure than leaf area, it may not provide the same level of precision in predicting basal area growth.

\section{Obtaining LAI for Many Stands}

Based on the results of the current investigation, one can estimate the LAI for many stands by using the following procedure:

1. Use principal component analysis to estimate the relationship between basal area growth and leaf area. In this study, LAI was estimated by first relating sapwood area to leaf area and then relating basal area to sapwood area. This minimizes the destructive sampling necessary to measure LAI since only one equation per species is likely to be needed. Alternatively, since the relationship between sapwood area and leaf area was found to be relatively stable, it could be taken from the literature. The relationship between basal area and sapwood area appears to be more stand specific and should be locally calibrated. Basal area growth of individual trees can either be obtained from repeated measurements on permanent sample plots or by taking increment cores and estimating the past 5-year diameter growth.

2. Measure (estimate) the basal area growth on additional stands using remeasurements or increment cores and use the relationship developed in step 1 to estimate the LAI.

3. At this point, stand LAI estimates can be used to calibrate instruments that measure stand LAI. These instruments can then be used to obtain LAIs of additional stands to drive growth models or, using the relationship from step 1, to estimate the basal area growth of additional stands.

By minimizing destructive sampling, this procedure requires less field time to obtain LAI estimates. The time saved can then be used to calibrate instruments that measure LAI using light interception or spectral reflectance. 


\section{Conclusions}

The relationship between basal area growth and leaf area can be used to predict LAI. By maintaining PSPs or coring trees and estimating the past basal area increment, a nondestructive method of estimating the LAI of forest trees is made available. Most optical nondestructive methods of estimating LAI include the silhouette area of the entire tree and, thus, may need correction factors for woody biomass and foliage overlap. Using basal area growth avoids this problem and has the additional advantage of distributing the leaf area by tree or diameter class if necessary. Basal area growth is useful as a stand characteristic and can be determined from routine sample plot measurements. Seasonal changes in SLA, particularly of current foliage, are important for indirect methods of estimating LAI that make assumptions about the light extinction coefficient.

Additional work is required to determine how the relationship between basal area growth and leaf area changes with stand age and geographic region. Thus far, results indicate that the relationship holds across the range of spacings normally encountered in jack pine and red pine and that it can be used to predict individual tree leaf area and stand LAI.

\section{Acknowledgments}

We thank anonymous reviewers for their constructive comments.

\section{References}

Bolstad, P.V. and S.T. Gower. 1990. Estimation of leaf area index in fourteen southern Wisconsin forest stands using a portable radiometer. Tree Physiol. 7: 115-124.

Deblonde, G. and M. Penner. 1994. Measuring leaf area index with the LI-COR LAI-2000 in pine stands. Ecology 75: 1507-1511

Decagon Devices. 1989. DIAS II users' manual. Decagon Devices, Pullman, WA.

Espinosa Bancalari, M.A., D.A. Perry and J.D. Marshall. 1987. Leaf area - sapwood area relationships in adjacent young Douglasfir stands with different early growth rates. Can. J. For. Res. 17: 174-180. Gholz, H.L., F.K. Fitz and R.H. Waring. 1976. Leaf area differences associated with old-growth forest communities in the western Oregon Cascades. Can. J. For. Res. 6: 49-57.

Kaufmann, M.R. and C.A. Troendle. 1981. The relationship of leaf area and foliage biomass to sapwood conducting area in four subalpine forest tree species. For. Sci. 27: 477-482.

Korol, R.L., S.W. Running, K.S. Milner and E.R. Hunt, Jr. 1991. Testing a mechanistic carbon balance model against observed tree growth. Can. J. For. Res. 21: 1098-1105.

Law, B.E., K.H. Rütters and L.F. Ohmann. 1992. Growth in relation to canopy light interception in a red pine (Pinus resinosa) thinning study. For. Sci. 38: 199-202.

Long, J.N. and F.W. Smith. 1988. Leaf area - sapwood area relations of lodgepole pine as influenced by stand density and site index. Can. J. For. Res. 18: 247-250.
Marchand, P.J. 1984. Sapwood area as an estimator of foliage biomass and projected leaf area for Abies balsamea and Picea rubens. Can. J. For. Res. 14: 85-87.

Marshall, J.D. and R.H. Waring. 1986. Comparison of methods of estimating leaf-area index in old-growth Douglas-fir. Ecology 67: 975-979.

McLeod, S.D. and S.W. Running. 1988. Comparing site quality indices and productivity in ponderosa pine stands of western Montana. Can. J. For. Res. 18: 346-352.

Oren, R., E.-D. Schulze, R. Matyssek and R. Zimmermann. 1986. Estimating photosynthetic rate and annual carbon gain in conifers from specific leaf weight and leaf biomass. Oecologia 70: 187-193.

Oren, R., R.H. Waring, S.G. Stafford and J.W. Barrett. 1987. Twenty-four years of ponderosa pine growth in relation to canopy leaf area and understory competition. For. Sci. 33: 538-547.

Pothier, D., H.A. Margolis and R.H. Waring. 1989. Patterns of change of saturated sapwood permeability and sapwood conductance with stand development. Can. J. For. Res. 19: 432-439.

Robichaud, E. and I.R. Methven. 1992. The applicability of the pipe model theory for the prediction of foliage biomass in trees from natural, untreated black spruce stands. Can. J. For. Res. 22: 1118-1123. Running, W.S., R.R. Nemani, D.L. Peterson, L.E. Band, D.F. Potts, L.L. Pierce and M.A. Spanner. 1989. Mapping regional forest evapotranspiration and photosynthesis by coupling satellite data with ecosystem simulation. Ecology 70: 1090-1101.

Shinozaki, K., K. Yoda, K. Hozumi and T. Kira. 1964a. A quantitative analysis of plant form - the pipe model theory. I. Basic analysis. Jpn. J. Ecol. 14: 97-105.

Shinozaki, K., K. Yoda, K. Hozumi and T. Kira. 1964b. A quantitative analysis of plant form - the pipe model theory. II. Further evidence of the theory and its application in forest ecology. Jpn. J. Ecol. 14: 133-139.

Smith, F.W., D.A. Sampson and J.N. Long. 1991. Comparison of leaf area index estimates from tree allometrics and measured light interception. For. Sci. 37: 1682-1688.

Snowdon, P. 1987. Predicting foliar biomass of Pinus radiata from basal area increment. Aust. For. Res. 17: 277-281.

Vose, J.M. and W.T. Swank. 1990. A conceptual model of forest growth emphasizing stand leaf area. Pages 278-287 In Process modeling of forest growth responses to environmental stress. R.K. Dixon, R.S. Meldahl, G.A. Ruark and W.G. Warren (eds.). Timber Press, Portland, OR.

Waring, R.H., H.L. Gholz, C.C. Grier and M.L. Plummer. 1977. Evaluating stem conducting tissue as an estimator of leaf area in four woody angiosperms. Can. J. Bot. 55: 1474-1477.

Waring, R.H., P.E. Schroeder and R. Oren. 1982. Application of the pipe model theory to predict canopy leaf area. Can. J. For. Res. 12: $556-560$.

Woods, K.E., A.H. Feiveson and D.B. Botkin. 1991. Statistical error analysis for biomass density and leaf area estimation. Can. J. For. Res. 21: 974-989.

Yang, K.C. and G. Hazenberg. 1992. Impact of spacings on sapwood and heartwood thickness in Picea mariana (Mill) B.S.P. and Picea glauca (Moench.) Voss. Wood and Fiber Sci. 24: 330-336. 